\title{
Reproduction of Cichla kelberi Kullander and Ferreira, 2006 introduced into an artificial lake in southeastern Brazil
}

\author{
Gomiero, LM.*, Villares Junior, GA. and Naous, F. \\ Departamento de Zoologia, Instituto de Biociências, Universidade Estadual Paulista - UNESP, \\ Av. 24-A, 1515, CP 199, CEP 13506-900, Rio Claro, SP, Brazil \\ *e-mail: leanmg@rc.unesp.br \\ Received September 18, 2007 - Accepted November 8, 2007 - Distributed February 28, 2009
}

(With 8 figures)

\begin{abstract}
The objective of this study was to characterize the reproduction of Cichla kelberi in an artificial lake, located in the municipality of Leme, in the state of São Paulo, Brazil. Breeding occurred in spring, and summer. The $\mathrm{L}_{50}$ and the $\mathrm{L}_{100}$ of this species were 192 and $235 \mathrm{~mm}\left(\mathrm{~L}_{50}\right)$, for males and females, respectively, and $290 \mathrm{~mm}\left(\mathrm{~L}_{100}\right)$ for both sexes. Spawning was parceled. The oocytes matured at a size of $428.4 \mu \mathrm{m}$, reaching their maximum at 2,203.2 $\mu \mathrm{m}$. A mean of fecundity were of 12,129.2 oocytes, with the mean of oocytes in each batch of 4,897.7. This species has external fertilization, is nonmigratory, and with parental care of the young. Various attributes of the peacock bass make their introduction a temptation. However, due to their feeding and reproductive characteristics, they have no natural predators, making it difficult to control their population growth or eradicate them.
\end{abstract}

Keywords: exotic specie, fish, peacock bass, reproduction, Cichla kelberi.

\section{Reprodução de Cichla kelberi Kullander and Ferreira, 2006 introduzidos em um lago artificial no Sudeste do Brasil}

\begin{abstract}
Resumo
O objetivo do estudo foi caracterizar a reprodução de Cichla kelberi em um lago artificial no município de Leme, Estado de São Paulo, Brasil. A época reprodutiva ocorreu na primavera e verão. $\mathrm{OL}_{50}$ e o $\mathrm{L}_{100}$ desta espécie foram de 192 e $235 \mathrm{~mm}\left(\mathrm{~L}_{50}\right)$ para machos e fêmeas, respectivamente e $290 \mathrm{~mm}\left(\mathrm{~L}_{100}\right)$ para ambos os sexos. A desova foi do tipo parcelado. O tamanho dos ovócitos maduros foi de 428,4 $\mu \mathrm{m}$, atingindo o máximo em 2.203,2 $\mu \mathrm{m}$. A média da fecundidade foi de 12.129,2 ovócitos com média de cada desova de 4.897,7 ovócitos. Esta espécie adequou-se à definição de peixes com fecundação externa, não migradoras e com cuidado parental da prole. Os atributos para a introdução dos tucunarés podem ser tentadores. Porém, suas características reprodutivas e alimentares fazem com que não existam competidores ou predadores naturais e, assim, a sua expansão populacional seja de difícil controle e erradicação.
\end{abstract}

Palavras-chave: espécie exótica, peixe, tucunarés, reprodução, Cichla kelberi.

\section{Introduction}

Aquatic environments in southeastern Brazil have been subjected to considerable alterations, with a large number of hydroelectric reservoirs and artificial lakes created for pay-to-fish and other recreational activities. As a result, the natural structure of the icthyofauna in these areas is in obvious decline and very susceptible to the introduction of new species that may be disseminated purposefully or casually through the connectivity of the bodies of water. The species of Cichla are frequently introduced, mainly because of their flavorful meat, their attractiveness for sport fishing, and for the control of other species (Zaret, 1980), such as tilapia and piranha (Agostinho and Julio Jr., 1996). However, the introduction of large piscivores provokes a simplifi-

cation in the structure of fish communities (Santos and Formagio, 2000), with possible cascade effects in the entire trophic chain (Zaret and Paine, 1973). All knowledge regarding the biology of this species in the new environment is important for future control measures, since eradication is practically impossible, as is foreseeing the damage caused in these environments (LoweMcConnell, 1990).

Cyclids develop parental care of the eggs, larvae, and young (McKaye, 1977) in a wide variety of ways, such as guarders of the substrate or mouth guarders; and with respect to sex, the care may be provided by both parents, by the female only, or by the male only (Goodwin et al., 1998). 
Species of the genus Cichla reproduce in lentic environments. The mates dig nests in shallow locales where the spawning and the early developmental stages of the fry occur, reaching sexual maturity in the first year of life (Braga, 1952; Novoa, 1996). The main reason for the preference for lentic environments is the availability of zooplankton to feed the young (Zaret, 1980). Comparatively, Cichla monoculus (Spix and Agassiz, 1831) has been more successful in occupying lakes and reservoirs than environments with pronounced seasonal variations in the water level, such as the floodplain of the upper Paraná River (Espinola, 2005).

In more seasonal natural areas, the species of Cichla may spawn only once a year (due to cost of parental care, of intra- and inter-specific competition, etc.), while in less seasonal reservoirs and artificial lakes, spawning may occur various times a year (Jepsen et al., 1999). Fecundity also shows an adaptive variation, reflecting the life conditions of the population, between populations, and among species (Vazzoler, 1996).

The aim of this study was to characterize the reproduction of Cichla kelberi in an artificial lake (Leme-SP) based on the length structure, sexual proportion, reproductive period, length of first gonadal maturation for both sexes, gonadossomatic relation (GSR) of males and females, oocyte development, type of spawn and fecundity.

\section{Material and Methods}

The lake is located in a tropical area $\left(47^{\circ} 18^{\prime} \mathrm{W}\right.$ and $22^{\circ} 13^{\prime} \mathrm{S}$ ) in the municipality of Leme, in the state of São Paulo. The lake was built over 50 years ago and has about $2.5 \mathrm{~km}$ of shoreline, a length of $860 \mathrm{~m}$ between the two most distant points, and $83 \mathrm{~m}$ between the closest two points, with a flooded area of about $360,000 \mathrm{~m}^{2}$. The depth of the lake is quite variable (1-9 m), and the shorelines are shallow, varying from a few centimeters to $1 \mathrm{~m}$, although at some points the depth at the lake edges exceeds $3 \mathrm{~m}$. The identification of specimens was made through scale counts in lateral lines (Kullander and Ferreira, 2006). Twenty years ago, two species of peacock bass were introduced, Cichla kelberi (from the Tocantins basin) and Cichla piquiti Kullander and Ferreira, 2006, with only the former currently being fished in the lake. These introductions were done with the objective of controlling populations of another exotic fish species, the tilapia (Oreochromis niloticus Linnaeus, 1757 and Tilapia rendalli Boulenger, 1912).

The climate is typical of tropical regions, with a mean annual temperature of $21^{\circ} \mathrm{C}$ and mean annual rainfall of $1,400 \mathrm{~mm}$. There are two typical seasonal periods: the hot and rainy period, which begins in October and lasts until April, and a colder, dry season, from May to September.

A total of 14 samples were made monthly in November and December 2005 and from April 2006 to March 2007. Each collection period lasted eight hours
(9:00 AM-5:00 PM). The collections were carried out in the whole lake by three people using fishing poles and artificial bait (baitcasting). This type of fishing is effective for the capture of peacock bass in a wide variety of environments (Taphorn and Duque, 1996; Jepsen et al., 1999). These fish are adapted to clear water and are visually oriented, moving mainly during the day, which makes it difficult to capture using simple net (Braga and Gomiero, 1997; Winemiller, 2001; Gomiero and Braga, 2003a).

Each individual was measured: total length (mm), total mass (grams), sex, and gonad maturation stage (Braga, 1990).

The population structure was analyzed according to length class per sex in each period of collection, as to the variations in the proportion of the sexes (sex-ratio).

The maturation stage of each specimen was determined macroscopically, considering coloration, transparency, superficial vascularization, and, for ovaries, the visualization and appearance of the oocytes. In agreement to a previously established scale, four different maturation stages were considered: A: immature, B: in maturation, C: mature, and D: spent (Vazzoler, 1996).

The G-test was employed to ascertain the stages of maturity (A, B, C and D) and number of immatures, females and males captured in the samples (Vanzolini, 1993).

The reproductive period was analyzed according to the variation of the frequencies of the different maturation stages during the collecting periods and sample sites.

The $\mathrm{L}_{50}$ is the mean length of the first gonad maturation at which $50 \%$ of the individuals are adult, in other words, individuals that have begun the reproductive cycle. The length at which all individuals are apt for reproduction is represented by $\mathrm{L}_{100}$, parameters estimated according to Vazzoler (1996)

The gonadossomatic relation is determined by the ratio between the weight of the gonad and the body weight of each specimen, multiplied by 100 (percentage) (Vazzoler, 1996). The means of these relationships were determined in each stage of maturity for males, females, and immatures. The variations of the gonadossomatic relations of males and females according to period are also presented.

Fecundity was estimated according to the volumetric method (Vazzoler, 1996). Spawning type was estimated by graphing the data for oocyte diameters and the frequency. Spawning may be single, total, multiple, or intermittent, depending on the variations in the frequencies of the dissociated oocytes. Once the individual fecundity was established for Cichla kelberi, we also estimated the relative fecundity in relation to length (FRL) and in relation to weight (FRW).

\section{Results}

Five hundred and forty-four (544) specimens of Cichla kelberi in the classes with total lengths of 35 to 
$455 \mathrm{~mm}$ were collected. The immature specimens were frequent in the classes with total lengths of 35 to $305 \mathrm{~mm}$, with males frequently ranging from 125 to $455 \mathrm{~mm}$ and females from 185 to $425 \mathrm{~mm}$ (Figure 1). An analysis of the Kolmogorov-Smirnov test (Vanzolini, 1993) applied to the frequency distributions of total lengths for males and females revealed a difference between these distributions $\left(\chi^{2}<0.05\right)$ (Figure 1).

The numerical frequency distribution of the sexes in each sampling indicated that immatures were frequent in every season of the year, with a greater number in the summer. Regarding the frequency of the immatures, both females and males, there was a difference $\left(\chi^{2}<0.05\right)$ in their monthly and seasonal distributions (Figures 2 and 3 ).
The stages of maturity analyzed for males and females indicated seasonal differences $\left(\chi^{2}<0.05\right)$ with mature (stage C) and spent (stage D) individuals frequent from the spring to summer (Figure 4).

The $\mathrm{L}_{50}$ and $\mathrm{L}_{100}$ of Cichla kelberi were about 192 and $235 \mathrm{~mm}\left(\mathrm{~L}_{50}\right)$, for males as for females, respectively, and $290 \mathrm{~mm}\left(\mathrm{~L}_{100}\right)$ for both sexes (Figure 5).

The highest gonadossomatic relation (GSR) values were obtained for mature individuals (stage C). The GSR values for females were above $2.3 \%$ (Figure 6).

The GSR for the males were relatively uniform throughout the collection period, with an increase in the spring. However, the values for the females decreased in October and always remained above the values for the males (Figure 7).

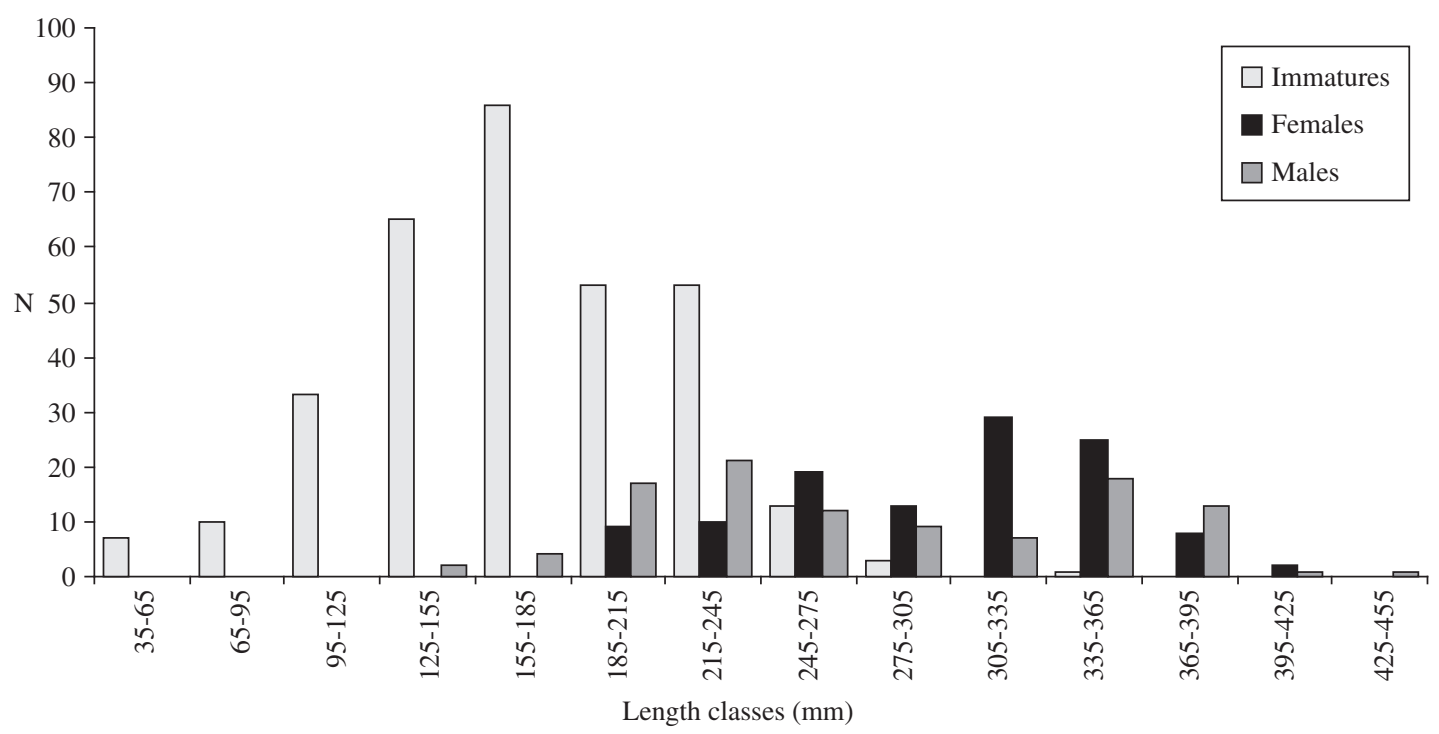

Figure 1. Numerical distribution for immatures, females and males of Cichla kelberi in the total-length classes.

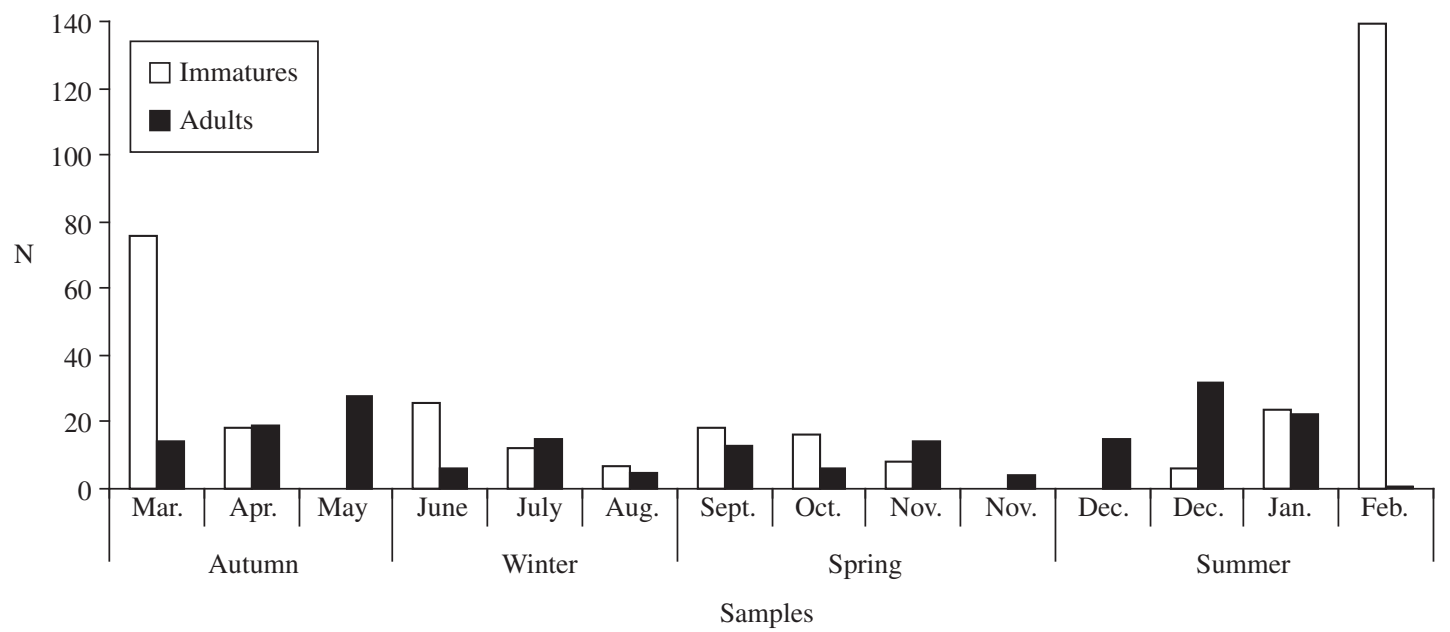

Figure 2. Numerical distribution of immature and adult individuals found in each period of sample. 


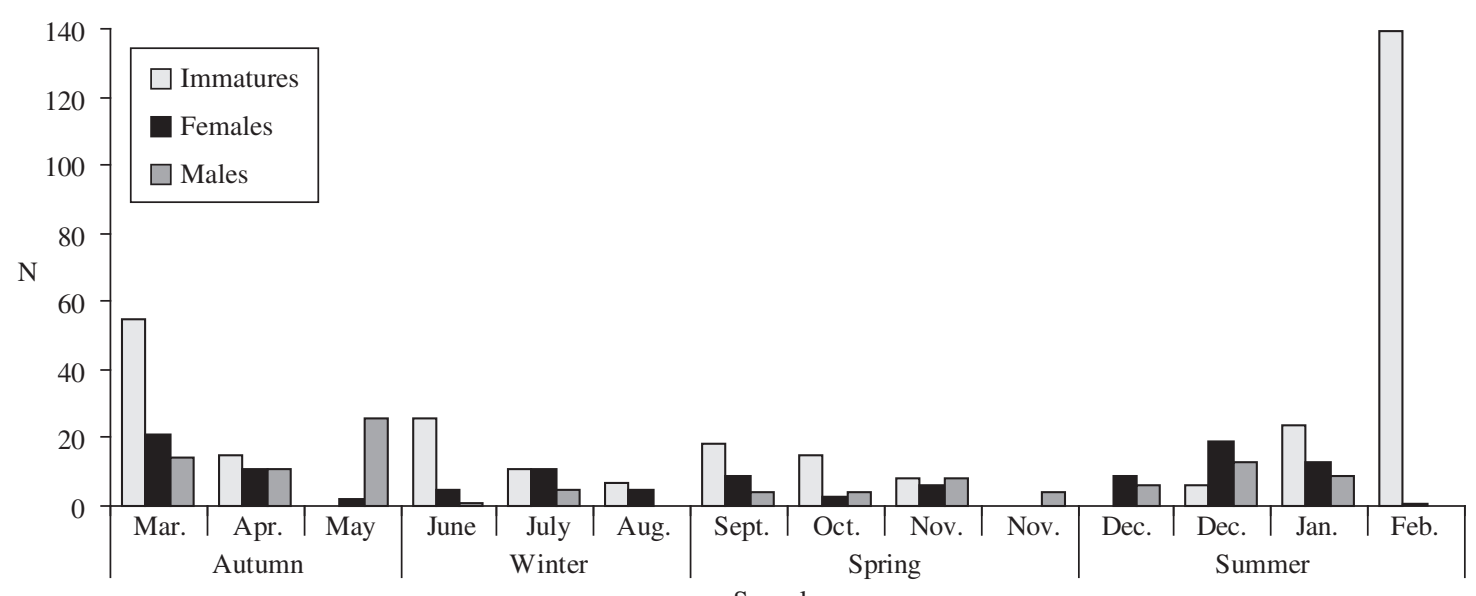

Figure 3. Numerical distribution of Cichla kelberi by sex, in each period of sample.

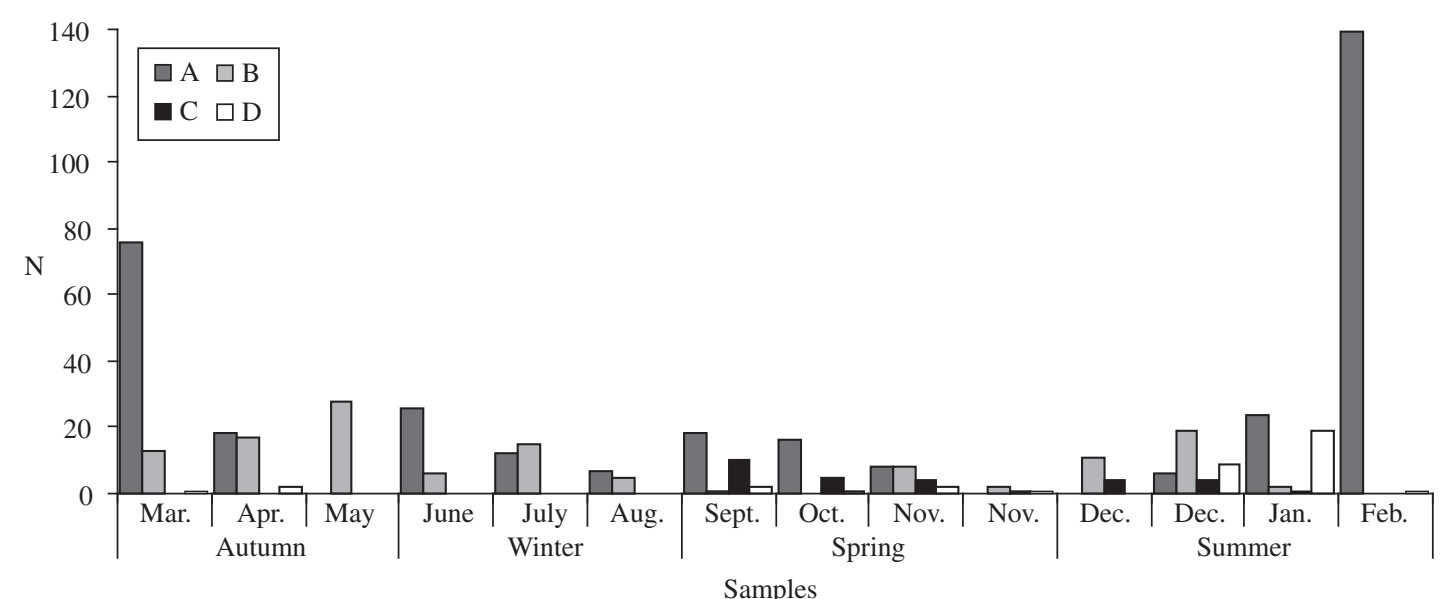

Figure 4. Numerical distribution of Cichla kelberi in the stages of gonadal maturity (A: immature, B: in maturation, C: mature, and D: spent) in each period of sample.

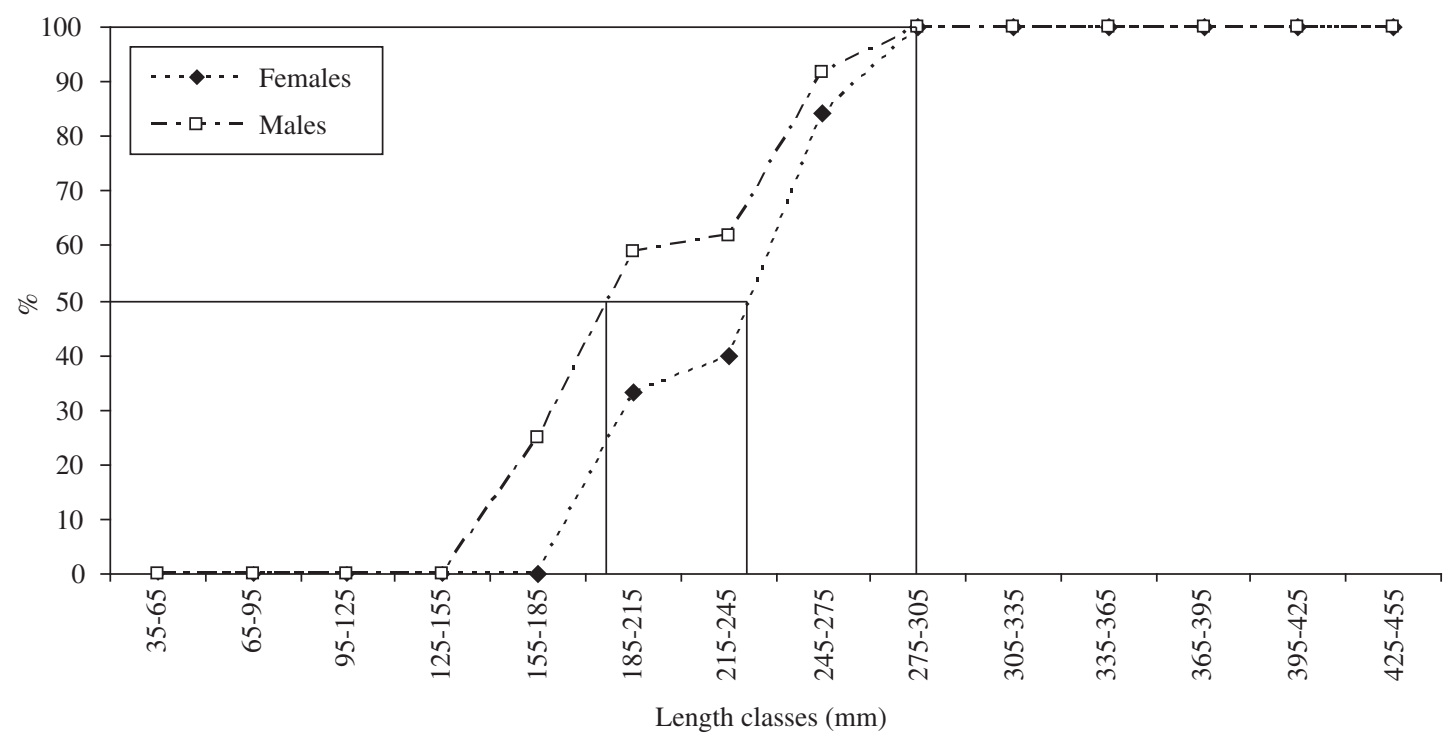

Figure 5. $\mathrm{L}_{50}$ and $\mathrm{L}_{100}$ of Cichla kelberi for females and males. 
The total number of oocytes (N') of the 23 pairs of ovaries analyzed from Cichla kelberi varied from 18,700 to 139,800 oocytes, with a mean of 53,965.2 \pm $5,707.5$ (SE). This number does not correspond to the fecundity, because it includes oocytes in the stock lot, in the process of maturation, and mature oocytes. Fecundity (N) varied from 4,708 to 22,572 oocytes, with a mean of $12,129.2 \pm 960.9$ (SE). The number of oocytes in each batch varied from 487 to 11,472 oocytes, with a mean of $4,897.7 \pm 814.4$ (SE). The mean FRL (fecundity relative to length) was $38.3 \pm 3.05$ (SE), and the mean FRW (fecundity relative to weight) was $22.48 \pm 1.74$ (SE).

The groups of frequency of occurrence by size (diameter) class of oocytes indicated that parceled spawning was occurring. The oocytes matured at a size of 428.4 $\mu \mathrm{m}$, reaching their maximum at 2,203.2 $\mu \mathrm{m}$.

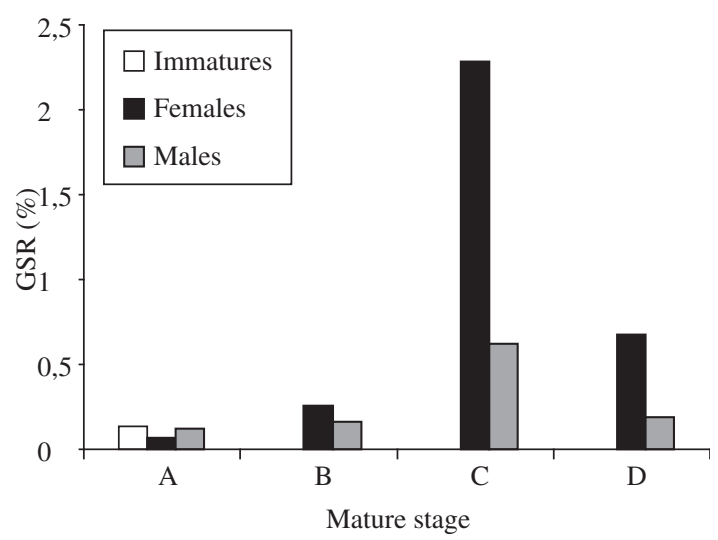

Figura 6. Gonadossomatic relation (GSR) for immatures, females, and males of Cichla kelberi at each stage of maturity (A: immature, B: in maturation, C: mature, and D: spent).

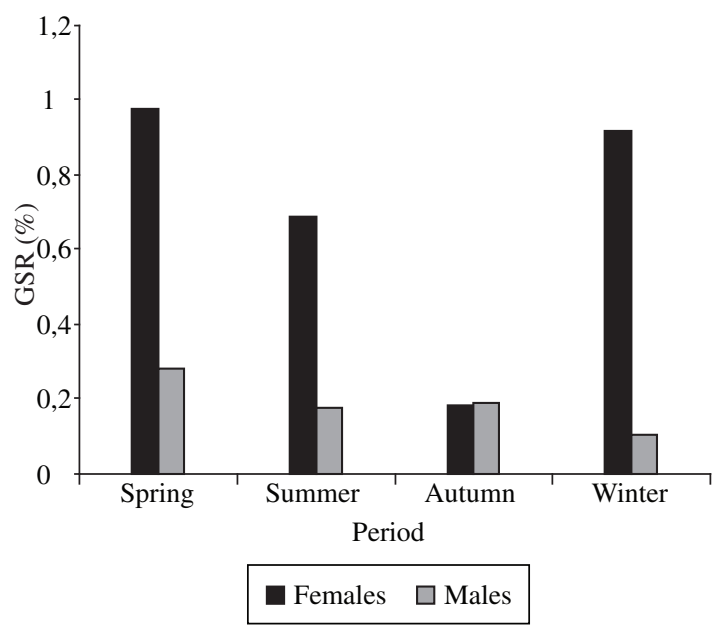

Figura 7. Gonadossomatic relation (GSR) for females and males of Cichla kelberi in each season of the year.
The stock lot included oocytes from 61.2 to $367.2 \mu \mathrm{m}$. Grouping the stage D (spent) ovaries showed that most oocytes over 1,407.6 $\mu \mathrm{m}$ were eliminated, and other lots were still found in these ovaries (Figure 8).

\section{Discussion}

Two species of peacock bass were introduced into the lake in Leme, however only Cichla kelberi were collected. The yellow cichlid (C. kelberi) presents high trophic plasticity and reproductive adaptability in new environments (Novaes et al., 2004). In addition, this species appears to be more resistant to the seasonal differences in temperature in southeastern Brazil than the Cichla piquiti (blue peacock bass).

The distribution of lengths of Cichla kelberi showed various modals corresponding to different age groups, which is common for the genus Cichla (Novoa, 1996; Gomiero and Braga, 2003a). The various modals of length, mainly for the immatures, correspond to a prolonged reproductive period and parceled spawning periods. The length distributions were different for the males and females, with the former reaching greater lengths than the latter. The same has been reported for other species of Cichla (Fontenele, 1950; Lowe-McConnell, 1969; Taphorn and Duque, 1996; Câmara et al., 2002; Chellappa et al., 2003; Gomiero and Braga, 2003a; 2003b; Muñoz et al., 2006). On the other hand, no differences in length were found between the sexes for Cichla temensis (Humboldt, 1821), Cichla orinocensis (Humboldt, 1821) and Cichla intermedia (Machado-Allison, 1971) in Venezuela (Jepsen et al., 1999). The only report of female length exceeding that of males was for C. monoculus $(=$ C. kelberi) in the Corumbá reservoir (GO) (Espinola, 2005). This disparity in the size structure and density of the peacock bass among locales and species may be justified by pressures resulting from fishing and maturation of the environments (Winemiller, 2001). The distributions of length of the introduced peacock bass vary according to the times they were introduced, the characteristics of the ecosystem, and interactions among fish species in these locales (Gomiero and Braga, 2003b).

There is competition among cichlids for spawning locales, with space for reproduction being a limited resource (McKaye, 1977; 1984). During sampling, certain shoreline areas (shallow with muddy bottoms) presented a greater number of nests and mated pairs of $C$. kelberi. In cichlids that practice bi-parental care, there is a division of labour, wherein the females guard the eggs and larvae while the males patrol and repel any possible predators (Barlow, 1974). Thus, larger males would have the advantage in the determination of territories at the initiation of the reproductive season and in the protection of the offspring (Zaret, 1980).

For species that develop bi-parental care, one would expect any difference in the proportion of males to females. The proportions of captured male and female of the peacock bass may be the same in environments where they 

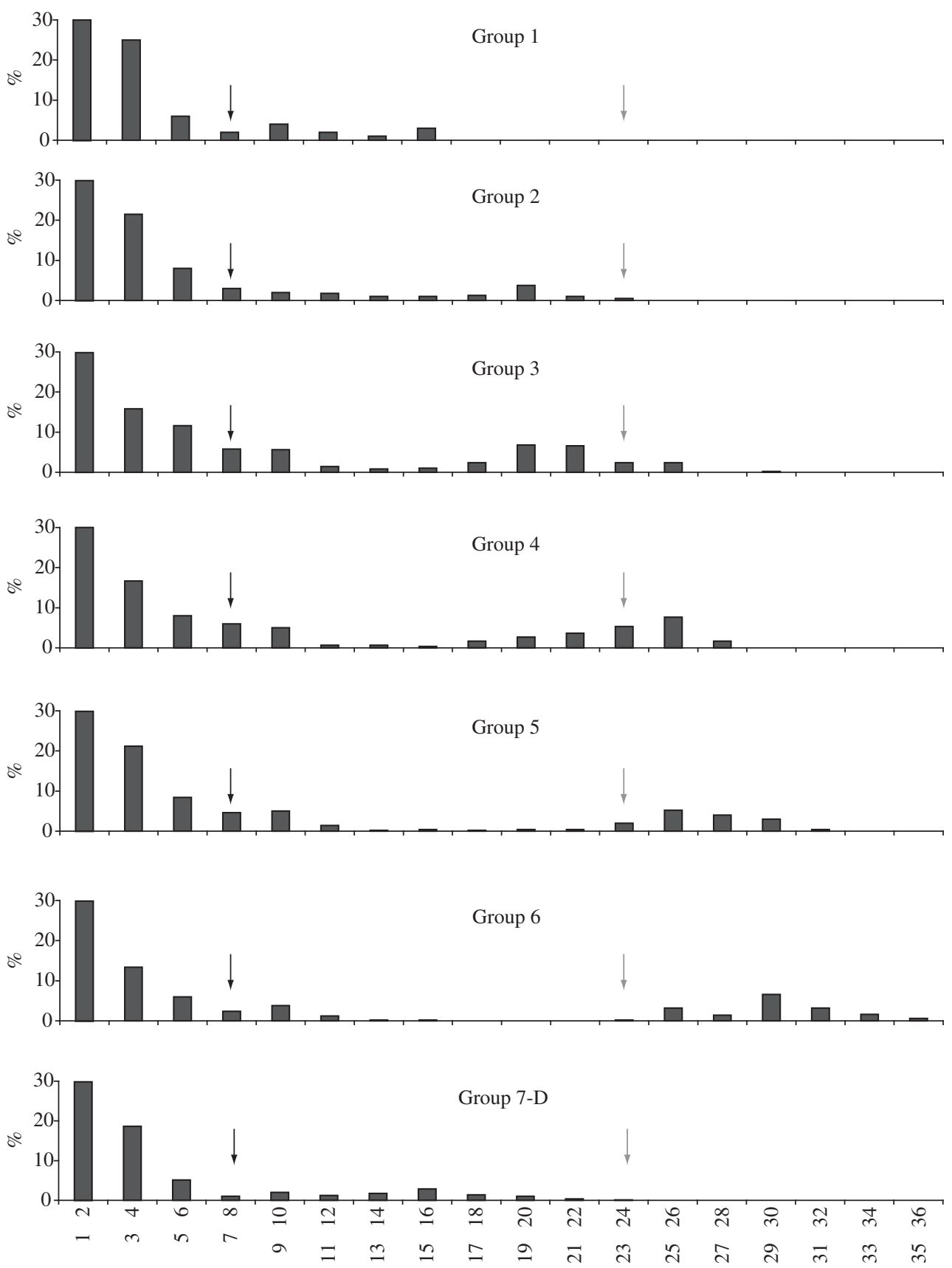

Classes of oocyte diameters

Figure 8. Frequency (in percentage) of the diametrical classes of oocytes, in d.o.m. (division of ocular micrometer) equivalent to 61.2 micrometer, of Cichla kelberi divided into groups (1-6: Groups of ovaries in increasing maturation stages of the oocytes, and 7: Group of spent ovaries). Black arrows indicate the size above which the oocytes become mature, and gray arrows indicate the size above which the oocytes are spawned in each batch.

were introduced (Câmara et al., 2002; Chellappa et al., 2003; Espinola, 2005) or different in natural environments (Jepsen et al., 1997; Muñoz et al., 2006). Mortality can be unequal between the sexes (Vazzoler, 1996), causing a difference in the proportion between males and females. In addition, during the reproductive season, there is a ten- dency to catch more males than females when fishing with artificial bait because of the males' aggressiveness to defend their territory, or the shoaling of the juveniles against any type of invader (Jepsen et al., 1997).

Previously published data on reproductive aspects of species of Cichla are summarized in Table 1. 


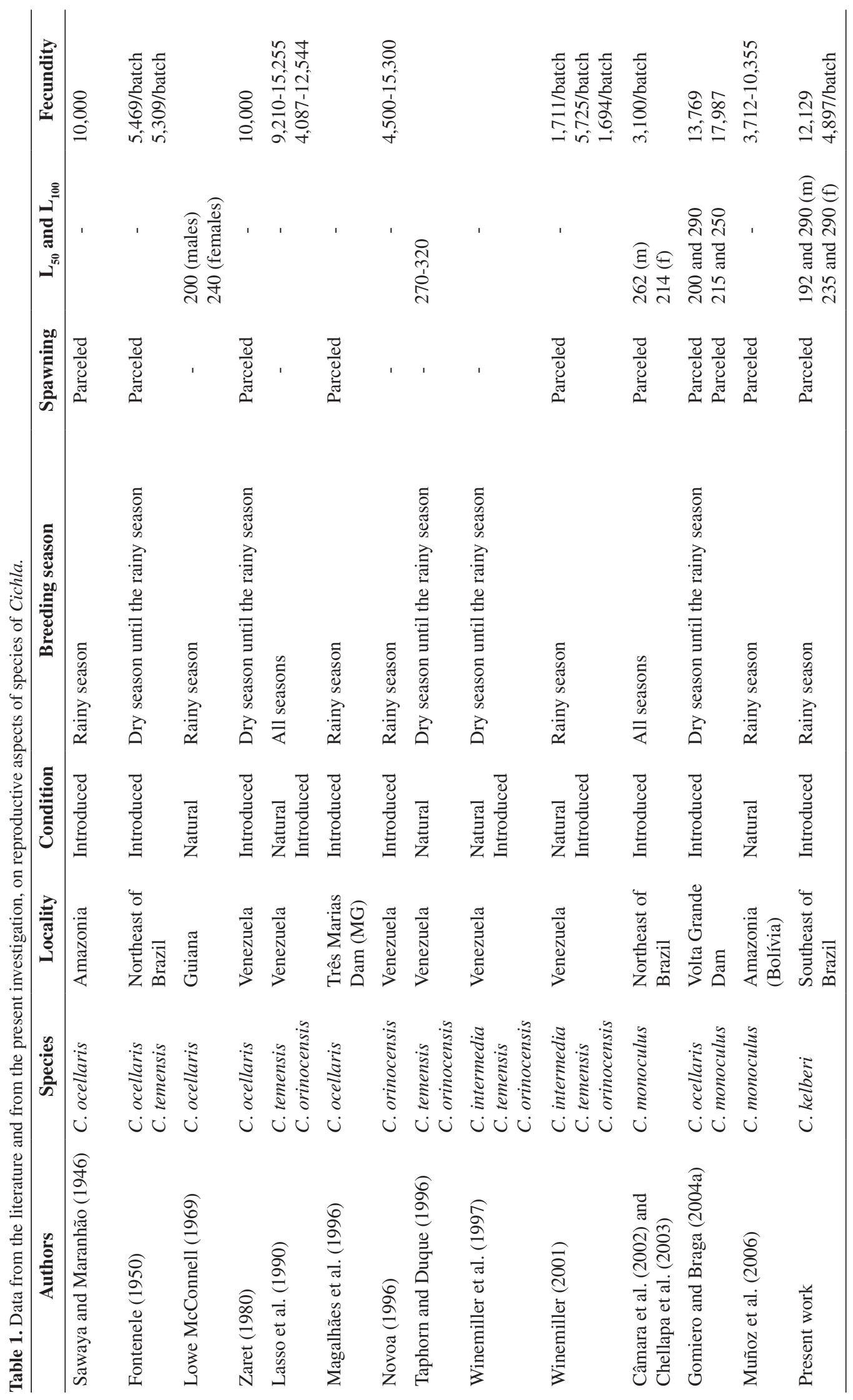


Immatures were common during all seasons of the year, providing evidence of the long reproductive period and continuous recruitment of $C$. kelberi. The long reproductive period for species of Cichla has been observed in natural environments as well as in lakes and reservoirs where the species had been introduced (Table 1). In artificial reservoirs, juveniles $(<4 \mathrm{~cm})$ were recorded in all the collections, with peaks in the rainy season (Espinola, 2005). In the study area, in addition to the juveniles, spent individuals (D) were also found to be more frequent in the rainy season. The synchrony of the reproduction can be explained by the availability of food resources for the juveniles. Also, the reproductive period of the predator fish precedes that of the foraging fish (McKaye, 1984; Taphorn and Duque, 1996). In July and mainly in August, nests were found dug around the edges of the lake in Leme, and mated pairs of tilapia, with reproductive periods preceding that of C. kelberi. Shoals of juvenile tilapia of varying size occurred throughout the reproductive period of the peacock bass. Tilapia were a common food item for the cichlids, Cichla ocellaris (Bloch and Schneider, 1801) and C. monoculus, in the UHE reservoir in Volta Grande (MG-SP) (Gomiero and Braga, 2004b).

The lengths of the first gonadal maturation of the C. kelberi were, in some cases, shorter than those reported in the literature (Table 1). In introduced species, rapid population growth occurs causing a large number of individuals to mature and reproduce in smaller size (nanism) (Agostinho and Julio Jr., 1996). Thus, it was inferred that, during the collection period, there was an overpopulation of $C$. kelberi with no natural predators and also with adequate food resources to develop fully.

The peaks in gonadossomatic relation (GSR) of C. kelberi occurred at the end of the dry season and throughout the rainy season, coinciding with the report by Chellappa et al. (2003). This relation was consistently higher for females than males for mature (C) and spent (D) individuals. The relatively high GSR for the state of maturity (D) corroborates the parceled spawning of the species, making it clear that the lots of maturing oocytes remain in the ovaries. The low gonadossomatic relation in the males can be explained by the absence of sperm competition, spawning in lentic environments, and fecundity of the females (Stockley et al., 1997).

Although most species of cyclids are able to multiple spawn during the year, fluctuations in food resources and availability of spawning locales can induce reproductive seasonality. The ability to alter the period and type of spawning, as well as fecundity and length of maturation, guarantees recruitment and survival of the species in different environmental conditions (Lowe-McConnell, $1969 ; 1999)$. The sizes of the maturing and mature oocytes approximated those previously reported for C. ocellaris and C. monoculus (Gomiero and Braga, 2004a) and for C. ocellaris introduced in the Três Marias Reservoir (MG) (Magalhães et al., 1996). The distribution of the diameters of the oocytes and the fecundity of
C. kelberi were equivalent to non-migratory species with external fertilization and parental care (Vazzoler, 1996).

The attributes of peacock bass with respect to recreational fishing, quality of the meat, and control of other species make it tempting to introduce them in any natural or artificial environment. However, to their reproductive characteristics, they have no natural competitors or predators in these new environments, leading to extraordinary population growth and difficult or impossible control and eradication.

\section{References}

AGOSTINHO, AA. and JULIO Jr., HF., 1996. Peixes de outras águas. Ciência hoje, vol. 21, no. 124, p. 36-44.

BARLOW, GW., 1974. Contrasts in social behavior between Central American cichlid fishes and coral-reef surgeon fishes. American Zoologist, vol. 14, no. 1, p. 9-34.

BRAGA, FMS., 1990. spectos da reprodução e alimentação de peixes comuns em um trecho do rio Tocantins entre Imperatriz e Estreito, Estados do Maranhão e Tocantins, Brasil. Brazilian Journal of Biology = Revista Brasileira de Biologia, vol. 50, no. 3, p. 547-558.

BRAGA, FMS. and GOMIERO, LM., 1997. Análise da pesca experimental realizada no reservatório de Volta Grande, rio Grande (MG/SP). Boletim do Instituto de Pesca, vol. 24, no. único, p. 131-138.

BRAGA, R., 1952. Ninhos de tucunarés Cichla temensis Humboldt e Cichla ocellaris Bloch \& Schneider. Brazilian Journal of Biology = Revista Brasileira de Biologia, vol. 12, no. 3, p. 273-278.

CÂMARA, MR., CHELLAPPA, NT. and CHELLAPPA, S., 2002. Ecologia reprodutiva do Cichla monoculus, um ciclídeo amazônico no semi-árido do Rio Grande do Norte. Acta Limnologica Brasiliensis, vol. 14, no. 2, p. 9-16.

CHEllAPPA, S., CÂMARA, MR., CHELlAPPA, NT., BEVERIDGE, MCM. and HUNTINGFORD, FA., 2003. Reproductive ecology of a neotropical cichlid fish, Cichla monoculus (Osteichthyes: Cichlidae). Brazilian Journal of Biology = Revista Brasileira de Biologia, vol. 63, no. 1, p. 17-26.

ESPINOLA, LA., 2005. Tática reprodutiva e estrutura da população de Cichla monoculus Spix \& Agassiz, 1831 (Perciformes, Cichlidae) em ambientes com diferentes regimes hidrológicos. Maringá: Universidade Estadual de Maringá. 23 p. Dissertação de Mestrado.

FONTENELE, O., 1950. Contribuição para o conhecimento da biologia dos tucunarés (Actinopterygii, Cichlidae), em cativeiro. Aparelho de reprodução. Hábitos de desova e incubação. Brazilian Journal of Biology = Revista Brasileira de Biologia, vol. 10, no. 4, p. 503-519.

GOMIERO, LM. and BRAGA, FMS., 2003a. Pesca experimental do tucunaré, gênero Cichla (Osteichthyes, Cichlidae), no reservatório da UHE de Volta Grande, rio Grande (48 $25^{\circ}$ $\left.47^{\circ} 35^{\prime} \mathrm{W}, 19^{\circ} 57^{\prime}-20^{\circ} 10^{\prime} \mathrm{S}\right)$. Boletim do Instituto de Pesca, vol. 29 , no. 1, p. $29-37$

-, 2003b. Relação peso-comprimento e fator de condição para Cichla ocellaris e Cichla monoculus (Perciformes, Cichlidae) 
no reservatório de Volta Grande, rio Grande-MG/SP. Acta Scientiarum, vol. 25, no. 1, p. 79-86.

- 2004a. Reproduction of species of the genus Cichla in a reservoir in southeastern Brazil. Brazilian Journal of Biology = Revista Brasileira de Biologia, vol. 64, no. 3B, p. 613-624.

-, 2004b. Feeding of introduced species of Cichla (Perciformes, Cichlidae) in Volta Grande reservoir, river Grande (MG/SP). Brazilian Journal of Biology = Revista Brasileira de Biologia, vol. 64, no. 4, p. 787-795.

GOODWIN, NB., BALSHINE-EARN, S. and REYNOLDS, JD., 1998. Evolutionary transitions in parental care in cichlid fish. Proceedings Royal Society London B, vol. 265, no. 1412, p. 2265-2272.

JEPSEN, DB., WINEMILLER, KO. and TAPHORN, DC., 1997. Temporal patterns of resource partitioning among Cichla species in a Venezuelan blackwater river. Journal of Fish Biology, vol. 51, no. 6, p. 1085-1108.

JEPSEN, DB., WINEMILLER, KO., TAPHORN, DC. and RODRIGUEZ OLARTE, D., 1999. Age structure and growth of peacock cichlids from rivers and reservoirs of Venezuela. Journal of Fish Biology, vol. 55, no. 2, p. 433-450.

KULLANDER, SO. and FERREIRA, EJG., 2006. A review of the South American cichlid genus Cichla, with descriptions of nine new species (Teleostei: Cichlidae). Ichthyological Exploration Freshwaters, vol. 17, no. 4, p. 289-398.

LASSO, CAA., NOVOA, D. and RAMOS, F., 1990. La ictiofauna del lago de Guri: composición, abundancia y potencial pesquero. Parte I: Consideraciones generales e inventario de la ictiofauna del lago de Guri con breve descripción de las especies de interes para la pesca deportiva y comercial. MEMORIA, vol. 49 , no. 131 , p. 141-158.

LOWE-McCONNELL, RH., 1969. The cichlid fishes of Guyana, South America, with notes on their ecology and breeding behaviour. Zoological Journal of the Linneum Society, vol. 48 , no. 2 , p. 255-302.

-, 1990. Summary address: rare fish, problems, progress and prospects for conservation. Journal of Fish Biology, vol. 37, no. 5a, p. 263-269.

-, 1999. Estudos ecológicos de comunidades de peixes tropicais. In VAZZOLER, AEAM., AGOSTINHO, AA. and CUNNIGHAN, P. (Trads.). São Paulo: Universidade de São Paulo. 535 p.

MAGAlHÃes, ALB., SATO, Y., RIZZO, E., FERREIRA, RMA. and BAZZOLI, N., 1996. Ciclo reprodutivo do tucunaré Cichla ocellaris (Schneider, 1801) na represa de Três Marias, MG. Arquivo Brasileiro de Medicina Veterinária e Zootecnia, vol. 48 , no. 1 , p. $85-92$.

McKAYE, KR., 1977. Competition for breeding sites between the cichlid fishes of lake Jiloá, Nicaragua. Ecology, vol. 58, no. 2, p. 291-302.
-, 1984. Behavioral aspects of cichlid reproductive strategies: patterns of territoriality and brood defense in Central American substratum spawners and African mouth brooders. In POTTS, GW. and WOTTON, RJ. (Eds.). Fish reproduction: strategies and tactics. London: Academic Press. p. 245-273.

MUÑOZ, H., VAN DAMME, PA. and DUPONCHELLE, F., 2006. Breeding behaviour and distribution of the tucunaré Cichla aff. monoculus in a clear water river of the Bolivian Amazon. Journal of Fish Biology, vol. 69, no. 4, p. 1018-1030.

NOVAES, JLC., CARAMASCHI, EP. and WINEMILLER, KO., 2004. Feeding of Cichla monoculus Spix, 1829 (Teleostei: Cichlidae) during and after reservoir formation in the Tocantins river, central Brazil. Acta Limnologica Brasiliensis, vol. 16, no. 1, p. 41-49.

NOVOA, DFR., 1996. Aspectos generales sobre la biologia, pesqueria, manejo y cultivo del pavón (Cichla orinocensis y Cichla temensis) en el lago de Guri y otras áreas de la region Guayana. Natura, vol. 96, p. 34-39.

SANTOS, GB. and FORMAGIO, PS., 2000. Estrutura da ictiofauna dos reservatórios do rio Grande, com ênfase no estabelecimento de peixes piscívoros exóticos. Informe Agropecuário, vol. 21, no. 203, p. 98-106.

SAWAYA, P. and MARANHÃO, AA., 1946. A construção de ninhos e a reprodução de alguns peixes neotrópicos (Cichlidae - gen. Cichla e Astronotus). Boletim da Faculdade de Filosofia, Ciências e Letras da Universidade de São Paulo, vol. 11, p. $357-381$

STOCKLEY, P., GAGE, MJG., PARKER, GA. and MOLLER, AP., 1997. Sperm competition in fishes: the evolution of testis size and ejaculate characteristics. American Naturalist, vol. 149, no. 6, p. 933-954.

TAPHORN, DCB. and DUQUE, AB., 1996. Evaluación de la situación actual de los pavones, (Cichla sp.), en el Parque Nacional Capanaro - Cinaruco, Est. Apure, Venezuela. Natura, vol. 96 , p. 10-25.

VANZOLINI, PE., 1993. Métodos estatísticos elementares em sistemática zoológica. São Paulo: Ed. HUCITEC. 130 p.

VAZZOLER, AEAM., 1996. Biologia da reprodução de peixes teleósteos: teoria e prática. Maringá: Nupelia. 169 p.

WINEMILLER, KO., 2001. Ecology of peacock cichlids (Cichla spp.) in Venezuela. Journal of Aquariculture and Aquatic Science, vol. 9, p. 93-112.

WINEMILLER, KO., TAPHORN, DC. and BARBARINODUQUE, A., 1997. The ecology of Cichla (Cichlidae) in two blackwater rivers of southern Venezuela. Copeia, vol. 1997, no. 4, p. 690-696.

ZARET, TM., 1980. Life history and growth relationships of Cichla ocellaris, a predatory South American cichlid. Biotropica, vol. 12, no. 2, p. 144-157.

ZARET, TM. and PAINE, RT., 1973. Species introduction in a tropical lake. Science, vol. 182, no. 2, p. 449-455. 